\title{
Rearing practices identified as risk factors for ostreid herpesvirus 1 (OsHV-1) infection in Pacific oyster Crassostrea gigas spat
}

\author{
Julien Normand ${ }^{1,2, *}$, Jean-Louis Blin ${ }^{1,3}$, Aude Jouaux ${ }^{1,4,5}$ \\ ${ }^{1}$ Centre de Référence sur l'Huître, Université de Caen Basse Normandie, Caen, France \\ ${ }^{2}$ IFREMER LERN Port en Bessin, Station de Port-en-Bessin, Avenue Général de Gaulle, 14520 Port-en-Bessin, France \\ ${ }^{3}$ Synergie Mer Et Littoral, Zone conchylicole, 50560 Blainville sur mer, France \\ ${ }^{4}$ Université de Caen Basse-Normandie, 'Biologie des Organismes Marins et des Ecosystèmes Associés' (BioMEA), IBFA, \\ SFR ICORE, 14032 Caen Cedex, France \\ ${ }^{5}$ CNRS INEE, BioMEA, Caen, France
}

\begin{abstract}
Early detection of Pacific oyster spat infected with ostreid herpesvirus 1 (OsHV-1) could prevent introduction of OsHV-1-infected individuals into farming areas or onshore rearing facilities, thus reducing the risk of infection of naïve oysters in such production systems. Experiments were conducted on several hundred oyster spat provided by producers in order to examine whether early rearing practices could be considered as potential risk factors for (1) OsHV-1 infection as detected by molecular methods and (2) spat mortality experimentally induced through thermal challenge. Spat groups collected on oyster beds and hatchery spat reared in growout areas during summer exhibited higher viral DNA contamination and mortalities during the trial than spat kept in onshore rearing facilities. Quantification of viral DNA before and during the trial showed that infection prevalence and intensity changed over time and revealed latent infection initially unsuspected in 3 of 10 groups. Thermal challenge induced a clear increase in the probability of detecting infected individuals, particularly for groups exhibiting significant prevalence of OsHV-1-contaminated spat prior to the challenge. The use of detection methods are discussed in relation to early rearing practices and disease control strategies.
\end{abstract}

KEY WORDS: Oyster spat · Epidemiology $\cdot$ OsHV-1 $\cdot$ qPCR $\cdot$ Thermal challenge

\section{INTRODUCTION}

To our knowledge, mortalities of Pacific oysters Crassostrea gigas were first reported in the middle of the $20^{\text {th }}$ century. Summer mortality events were first noted on the west coast of the USA in the late 1950s (Cheney et al. 2000), in Japan in 1961 (Mori 1979), in Mexico since 1997 (Chávez-Villalba et al. 2007) and in France for the last $20 \mathrm{yr}$ (Samain et al. 2007). Until 2008, mortality outbreaks observed in Pacific oyster stocks in France were a relatively scarce phenomenon, having a complex aetiology involving host, envi- ronment and pathogen (Samain et al. 2007). Along with environmental and oyster factors, several pathogens were found associated with these mortality events, including bacteria belonging to the genus Vibrio (Saulnier et al. 2010) and an ostreid herpeslike virus (Renault et al. 1994, 2000a). The first observation of herpes-like virus particles in oysters was by Farley et al. (1972), during a mortality outbreak in $C$. virginica associated with elevated temperature effluent from a power plant in the USA. In France, the association between a herpes-like virus and oyster mortality was reported for the first time in the early 1990s 
in hatchery-reared C. gigas larvae (Nicolas et al. 1992). Molecular studies then allowed the characterization of the viral genome and confirmed that the virus, named Ostreid herpesvirus 1 (OsHV-1), belongs to the family Malacoherpesviridae (Davison et al. 2009).

In 2008, heavy mortalities hit Pacific oyster spat in all French production sites during the spring and summer (Pernet et al. 2010, 2012, Dégremont 2011), resulting in 50 to $100 \%$ spat losses depending on site, origin of spat and rearing practices. The death rate declined over winter, but mortalities recommenced in spring 2009 and continued until 2013. A new variant of OsHV-1 emerged as a dominant genotype in association with the rapid increase of mortality in 2008, suggesting the emergence of a novel oyster disease (Segarra et al. 2010, Renault et al. 2012). Experimental challenges, made via the injection of viral particles or cohabitation of healthy oysters with symptomatic individuals, confirmed the high pathogenicity of OsHV-1 $\mu$ Var (Schikorski et al. 2011a,b, Y. He, A. Jouaux, S. Ford, M. Mathieu, C. LeLong \& X. Guo unpubl.), which is now considered the most probable causative agent of spat mortalities in France. Severe disease events associated with OsHV-1 were also reported in 2009 in Ireland (Peeler et al. 2012) and 2010 in Australia and New Zealand (Jenkins et al. 2013), suggesting that this virus is becoming a global problem for Pacific oyster culture.

To face this threat, producers and other stakeholders soon made clear their desire to reduce the spread of the disease. As there are no effective vaccines or treatments, health management strategies were based primarily on risk reduction through the restriction of oyster stock transfers between sites during summer months, at both regional and national scales (Murray et al. 2012). In parallel, different research teams intensified their efforts to gain knowledge of epidemiological aspects of oyster spat mortality (Peeler et al. 2012), and to develop more accurate and cost-effective molecular tools for the detection of infected individuals (Martenot et al. 2010). These tools are now routinely employed for the early detection of infectious sources, aiming at excluding OsHV-1infected spat from growout areas to reduce infection risk.

Several methods are now available to detect OsHV1 or to estimate viral loads in biological samples: light microscopy and electron microscopy (Renault et al. 1994), and molecular methods such as in situ hybridization (Arzul et al. 2002), PCR (Renault et al. $2000 \mathrm{~b}$ ) and quantitative PCR (qPCR; Pepin et al. 2008, Martenot et al. 2010). A novel method based on a thermal challenge in the lab was also developed to detect latent infections. The thermal challenge consisted of exposing a subsample of previously infected oysters to conditions that mimic field conditions under which mortality events occur. The method was inspired by previous work that identified temperature as a trigger for virus replication (Burge et al. 2006) and was first described by Petton et al. (2013). This protocol is currently considered the standard method for revealing latent infection in asymptomatic spat, although it could appear less specific than classical diagnostic tools based on molecular methods due to the fact that temperature could also trigger the replication of other pathogens (Petton et al. 2013).

Early detection of OsHV-1 is challenging. As with other members of the order Herpesvirales (Jones 2003), this virus may persist in its host after the primary infection, entering into a latency stage (Arzul et al. 2002). The seasonality of mortality outbreaks in spat and virus detection in relation to seawater temperature variation also suggests that OsHV-1 is able to reactivate from latency and that this is triggered by temperature increases (Le Deuff et al. 1996, Burge et al. 2006, Oden et al. 2011). The identification of several OsHV-1 genes involved in latency maintenance or in the lytic phase (Jouaux et al. 2013) strongly supports this hypothesis.

In this paper, we report an experimental study conducted to determine the evolution of OsHV-1 infection in different spat populations, in relation to potential risk factors. We employed different batches of young oysters $(<1 \mathrm{yr})$ from various origins and histories. Three methods for detection of early OsHV-1 infections were investigated: (1) qPCR immediately upon delivery of the spat, (2) mortality during a thermal challenge and (3) qPCR during thermal challenge.

\section{MATERIALS AND METHODS}

\section{Biological material and indicators of early rearing practices}

Ten groups of oyster spat were obtained from oyster growers during the winter and early spring of 2012. For each group, information was collected about the origin of spat (produced in a hatchery or collected on natural beds along the shore) and their potential exposure to OsHV-1 contamination, particularly during summer, when mortalities occurred (Table 1). 
As currently practiced, size-selective culling commonly induces high variability of spat size among groups. Knowing that physiological functions (such as food assimilation, oxygen consumption, subsequent growth and reproductive effort) are sizedependent in oysters (Pouvreau et al. 2006), we also measured mean individual mass and standard deviation by weighing 30 randomly selected spat in each population.

\section{Virus analysis}

Initial prevalence of OsHV-1 was estimated from 96 individuals, randomly sampled in each group upon spat delivery. Prevalence of OsHV-1 during the thermal challenge was estimated by sampling 15 living ind. group $^{-1}$ (5 in each replicate of challenge tanks), 3 wk after the beginning of the trial.

Genomic DNA from each spat sample was extracted individually on an EpMotion5075 automated pipetting system (Eppendorf) with the Nucleospin 96 Blood kit (Macherey Nagel) according to manufacturer's protocol. Quality and quantity of genomic DNA were estimated on a Nanodrop 2000 spectrophotometer (Thermoscientific). Due to the high number of individuals analysed for each group and condition, samples could only be tested individually.

Virus quantifications were based on the qPCR TaqMan protocol described by Martenot et al. (2010), using the same amplification protocol and primers. Following these authors, this particular quantification method offers the best guarantees for precision and quantification prediction, considering that standard precautions (such as cross-validation with alternative protocols and the use of various internal quantification calibrators) were taken during the

Table 1. Origin, history and individual mass (mean \pm SD) for Pacific oyster Crassostrea gigas spat groups used in this study. NSC: natural spat collection; exp.: exposed to intertidal rearing area

\begin{tabular}{|lclll|}
\hline Batch & $\begin{array}{c}\text { Spat } \\
\text { origin }\end{array}$ & $\begin{array}{c}\text { Intertidal } \\
\text { rearing }\end{array}$ & $\begin{array}{c}\text { Intertidal rearing } \\
\text { in summer }\end{array}$ & $\begin{array}{c}\text { Individual } \\
\text { mass }(g)\end{array}$ \\
\hline 1 & NSC & Yes-exp. & Yes-exp. & $0.40 \pm 0.03$ \\
2 & Hatchery & Yes-exp. & Yes-exp. & $0.70 \pm 0.01$ \\
3 & Hatchery & No-not exp. & No-not exp. & $0.64 \pm 0.05$ \\
4 & NSC & Yes-exp. & Yes-exp. & $0.19 \pm 0.01$ \\
5 & Hatchery & No-not exp. & No-not exp. & $0.17 \pm 0.01$ \\
6 & Hatchery & Yes-exp. & Yes-exp. & $0.21 \pm 0.01$ \\
7 & Hatchery & Yes-exp. & No-not exp. & $0.50 \pm 0.02$ \\
8 & NSC & Yes-exp. & Yes-exp. & $0.10 \pm 0.01$ \\
9 & Hatchery & Yes-exp. & No-not exp. & $0.31 \pm 0.01$ \\
10 & NSC & Yes-exp. & Yes-exp. & $0.14 \pm 0.01$ \\
\hline
\end{tabular}

development of the assay. Around 350 ng of DNA were used for the PCR reaction. A 5 concentration level standard control was added to each plate in order to establish the standard curve, and a negative control was also included to test for potential contamination. Virus quantity was reported as viral genomic units (VGU) $\mathrm{ng}^{-1}$ of genomic DNA extracted (Schikorski et al. 2011a,b, Burge \& Friedman 2012). The detection limit for the qPCR assay was 50 VGU. The thermocycler used for qPCR analysis was a CFX $96^{\mathrm{TM}}$ Real Time System C1000 TM Thermal Cycler (Biorad).

\section{Thermal challenge}

Experimental facilities were very similar to the ones described by Petton et al. (2013), consisting of a flow-through rearing system supplied with $1 \mu \mathrm{m}$ filtered seawater exposed to UV irradiation flowing at $100 \mathrm{ml} \mathrm{min}{ }^{-1}$, which is the current method used to prevent the entrance of viral particles in hatcheries. During the 4 wk trial, 3 replicates of 200 spat group $^{-1}$ were placed in $10 \mathrm{l}$ tanks receiving this flow-through water. Oysters were fed constantly ad libitum with Chaetoceros calcitrans $\left(49 \times 10^{6}\right.$ cells spat $\left.^{-1} \mathrm{~d}^{-1}\right)$ and maintained at $21 \pm 0.7^{\circ} \mathrm{C}$. Mortality was estimated at the end of the trial by calculating the percentage of dead individuals compared with the total starting number of spat.

\section{Statistical analyses}

All statistical analyses were conducted with $\mathrm{R}$ software, using the Epicalc (Chongsuvivatwong 2012) and MASS packages (Ripley et al. 2013). As a first step, we conducted a risk factor analysis considering the 3 following proxies for infection status as the outcomes: (1) frequency of OsHV-1 detection by qPCR on delivery of the spat, (2) mortality in the thermal challenge and (3) frequency of OsHV-1 detection by qPCR during the thermal challenge. We transformed the OsHV-1 qPCR values to produce a (binomial) variable as follows: viral detection was considered positive when quantification of the amount of OsHV-1 DNA exceeded 0.1 VGU ng ${ }^{-1}$ DNA (that is, the rounded-up nearest value of the detection limit: 0.14 VGU $\mathrm{ng}^{-1}$ ) and negative when it was less. 
We considered early rearing practices (origin of spat, rearing in the intertidal area, rearing in the intertidal area during summer) and mean individual mass as potential risk factors.

Due to the fact that oyster seed from 'natural' spat collections settle in the intertidal area during the summer period, only oysters from hatcheries could have avoided exposure to the virus when mortalities occurred, and 'rearing in the intertidal area' appeared logically nested in the 'origin' effect. Similarly, 'rearing in the intertidal area during summer' was nested within 'rearing in the intertidal area' (Fig. 1). The following analytical strategy was therefore employed:

(1) The effect of origin was first tested by contrasting between groups from hatchery or spat collection in the field, considering all groups.

(2) The effect of rearing in the intertidal area effect was tested within hatchery groups by contrasting exposed (reared in the intertidal area) and unexposed (never reared in the intertidal area) groups.

(3) The effect of rearing in the intertidal area during summer was tested within groups reared in the intertidal area, by contrasting exposed (reared in the intertidal area during summer) and unexposed (not reared in the intertidal area during summer) groups.

To this end, we used logistic (univariate) regression to fit models and estimate relevant odds ratios (OR) and $95 \%$ confidence intervals (CI). For binary independent variables (e.g. origin of spat, rearing in the intertidal area, rearing in the intertidal area during summer), we tested for the significance of the potential risk factor using a chi-squared test of independence, whereas a Wald-test was applied for the continuous variable, mean mass.

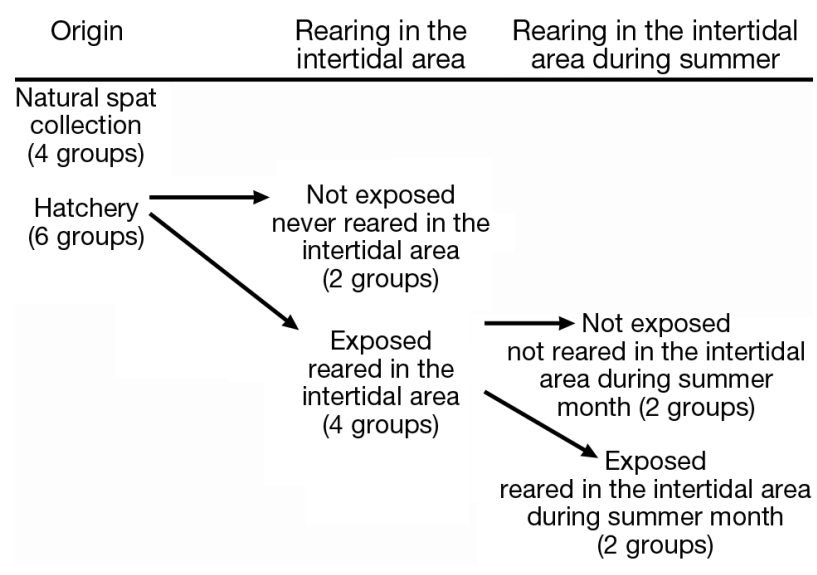

Fig. 1. Origin of Pacific oyster Crassostrea gigas spat and rearing practices, with the number of spat groups used in this study
As a second step, we focused on the evolution of OsHV-1 prevalence and load in response to thermal challenge and early rearing practices. To this end, we transformed the qPCR values to produce a discrete 'virus-load' class variable having 5 levels: Class $1=$ $0-0.1$, Class $2=0.1-1$, Class $3=1-10$, Class $4=$ 10-100, Class $5=10-1000 \mathrm{VGU} \mathrm{ng}^{-1}$ of oyster DNA. We then employed ordinal logistic regression with proportional odds assumption (Ananth \& Kleinbaum 1997) to model frequency by OsHV-1 class for each treatment (before or during the thermal challenge), origin and early rearing practice, using the same approach that we employed for risk factor analysis to model nested effects. We also tested for these effects on observed frequency by OsHV-1 class using the chi-squared test.

\section{RESULTS}

\section{Virus detection on delivery of the spat}

No OsHV-1 was detected in only 3 (Groups 3, 5 and 9; Table 1) of the 10 groups used in this study. Viral DNA was detected in a small fraction of the population in 4 groups: 3, 9, 1 and $4 \%$ in Groups 2, 7, 8 and 10 , respectively. The 3 remaining groups, 1, 4 and 6, had higher prevalences of 24, 19 and $24 \%$, respectively (Fig. 2a).

\section{Mortality during thermal challenge}

At the end of the experimental challenge, 6 groups had mean mortalities (among the 3 replicate tanks) greater than $20 \%$ (Groups 1, 2, 4, 6, 8 and 10), and 2 of these ( 8 and 10) were greater than $70 \%$ (Fig. 2b). Mortality rates in Group 8 ranged between 71 and $86 \%$. For Group 10, however, mortality greater than $70 \%$ was observed for only 1 of the replicates, whereas the other 2 experienced mortality around $23 \%$ (Fig. 2b). The 4 other groups $(3,5,7,9)$ had mortalities less than $5 \%$ at the conclusion of the thermal challenge (Fig. 2b).

\section{Virus detection during thermal challenge}

OsHV-1 DNA was detected in every group tested during the thermal challenge (Fig. 2c). Virus detection was more frequent in Groups 4, 6 and 8, ranging from $80 \%$ (12 positive cases among 15 samples) to 100\%. Group 1 exhibited intermediate prevalence, with $33 \%$ 

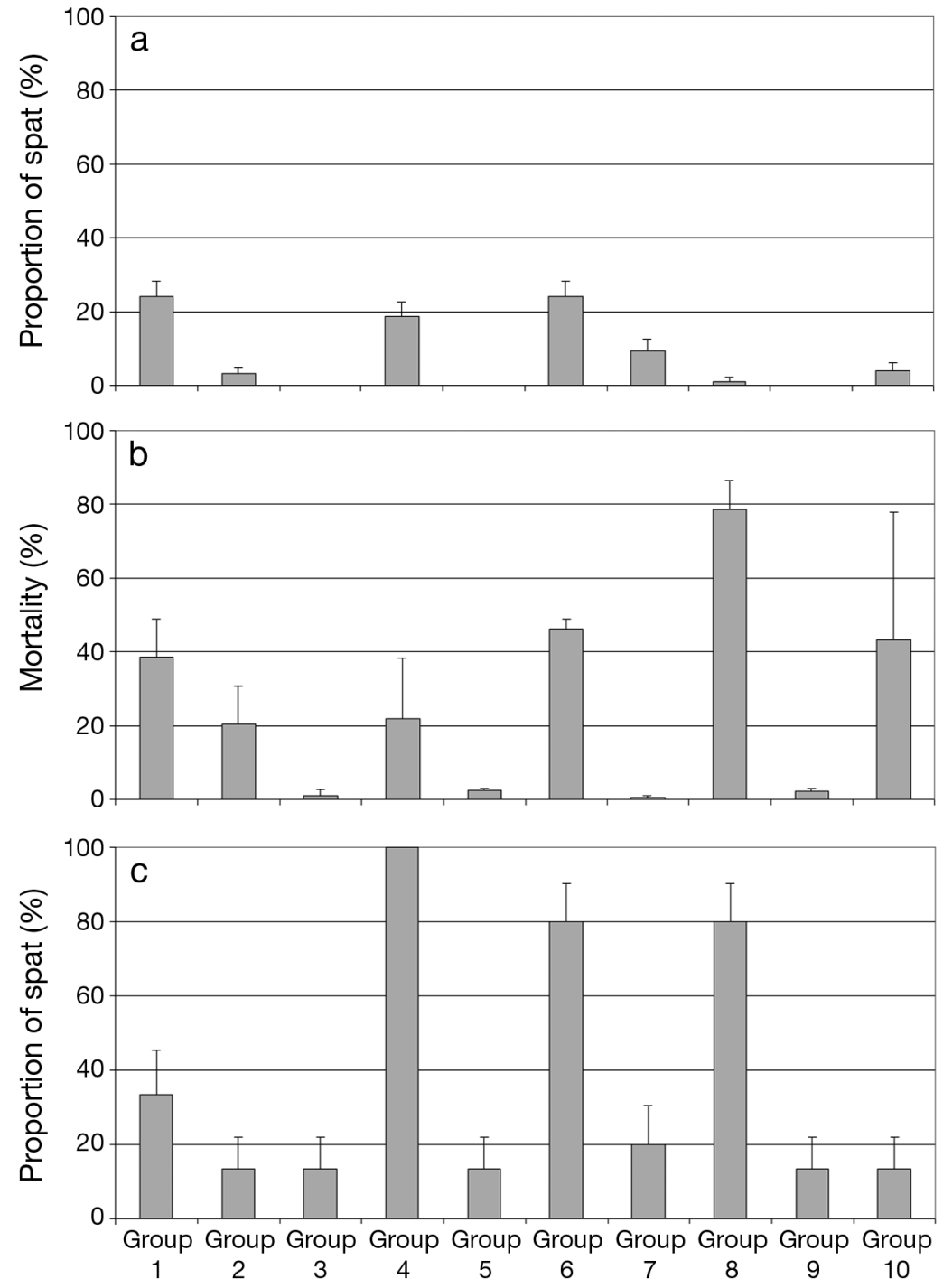

Fig. 2. Mean \pm SD of (a) proportion of Pacific oyster Crassostrea gigas spat with ostreid herpesvirus 1 (OsHV-1) $>0.1$ viral genomic units (VGU) ng $^{-1}$ among groups upon delivery of the spat $\left(\mathrm{n}=96\right.$ ind. group $\left.{ }^{-1}\right)$, (b) cumulative mortality $(\%)$ among groups at the end (4 wk) of the thermal challenge (mean \pm SD among tanks; $\mathrm{n}=200$ ind. $\operatorname{tank}^{-1}, 3$ tanks group ${ }^{-1}$ ) and (c) proportion of spat with OsHV-1 $>0.1 \mathrm{VGU} \mathrm{ng}^{-1}$ among groups after $3 \mathrm{wk}$ of thermal challenge $\left(n=15\right.$ ind. group $\left.^{-1}\right)$

(5/15) of the samples being positive. For the 6 remaining groups, OsHV-1 DNA was detected in only 2 or 3 individuals among the 15 tested (13 to $20 \%$; Fig. 2c).

\section{Risk factor analysis}

Rearing in the intertidal regions appeared to have a great influence on the probability of detecting OsHV-1 upon delivery of the spat (Table 2). Among Groups 3 and 5 (96 spat each) that were never reared in the intertidal area, no individual was found to be positive for the virus. Individuals not exposed in the field during summer, or (to a lesser extent) coming from the hatchery, were also less likely to be positive for the virus upon delivery (Table 2). The probability of detecting individuals infected by the virus increased from 2 to $14 \%$ when comparing hatchery-produced spat kept in onshore facilities during summer to those placed in the field. The OR for 'rearing in the intertidal area during summer' effect was estimated to be 6.5 (95\% CI, 2.9-16.1). In parallel, initial prevalence estimated by qPCR increased from 6 to $12 \%$ when comparing oyster spat from natural settlement instead of hatchery production, and the relevant OR was 2.1 (1.3-3.44; Table 2).

Among the groups that were maintained in the hatchery during summer, mortalities during the thermal challenge were less than $2 \%$, suggesting that they were protected from infection. Conversely, rearing in the intertidal area during summer, and to a lesser extent, the use of natural spat collected in the field, sharply increased mortalities during the thermal challenge (Table 2). For these 2 potential risk factors, estimated ORs were 32.9 (23.1-48) and 6 (5.3-6.9), respectively. Risk ratios indicated a 22.4-fold increase in the probability of dying during the thermal challenge when hatchery spat were reared in the intertidal area during summer, or an increase of 3.7-fold for spat from natural settlement compared with hatcheryproduced spat.

The probability of detecting OsHV-1 during the thermal challenge followed the same trend as that for mortality (Table 2). Mean prevalence estimated by qPCR was around $15 \%$ and did not appear to be significantly affected by rearing in the intertidal area; however, rearing in this region during summer significantly increased the probability of detecting OsHV-1 from 15 to $47 \%$, with a corresponding OR of 5 (1.6-15.4). Spat from natural recruitment were also more likely to be positive for the virus than hatchery seed. An estimated $6 \%$ of the oysters from hatcheries were infected after $3 \mathrm{wk}$ of thermal challenge, whereas $12 \%$ of natural spat were. The OR for origin effect was estimated to be 3.8 (1.8-8.1). 
Table 2. Effects of early rearing practices of Pacific oysters Crassostrea gigas (origin, rearing in the intertidal area during summer, rearing in the intertidal area) on (1) the probability of detecting ostreid herpesvirus (OsHV-1) upon spat delivery, (2) the probability for one spat to die during thermal challenge and (3) the probability of detecting OsHV-1 after thermal challenge. Chisquared values and associated probabilities with exact odds ratios (OR) and $95 \%$ confidence intervals $(\mathrm{CI})$ are shown. Origin effect: hatchery $=0$, natural spat collection $=1$; intertidal rearing effect: not exposed $=0$, exposed $=1$

\begin{tabular}{|c|c|c|c|}
\hline & Origin & $\begin{array}{l}\text { Intertidal } \\
\text { rearing }\end{array}$ & $\begin{array}{l}\text { Intertidal rearing } \\
\text { in summer }\end{array}$ \\
\hline \multicolumn{4}{|c|}{ OsHV-1 detection on spat delivery } \\
\hline$\chi^{2}$ & 10.4 & 9.2 & 28.1 \\
\hline $\mathrm{p}$ & 0.001 & $<0.0001$ & $<0.0001$ \\
\hline OR $(95 \% \mathrm{CI})$ & $2.1(1.3-3.44)$ & Infinite & $6.5(2.9-16.1)$ \\
\hline \multicolumn{4}{|c|}{ Mortality during thermal challenge } \\
\hline$\chi^{2}$ & 838.1 & 0.45 & 762.6 \\
\hline $\mathrm{p}$ & $<0.0001$ & 0.5 & $<0.0001$ \\
\hline OR $(95 \% \mathrm{CI})$ & $6(5.3-6.9)$ & $0.8(0.4-1.6)$ & $32.9(23.1-48)$ \\
\hline \multicolumn{4}{|c|}{ OsHV-1 detection during thermal challenge } \\
\hline$\chi^{2}$ & 14.8 & 0.1 & 10.5 \\
\hline $\mathrm{p}$ & $<0.0001$ & 0.72 & 0.001 \\
\hline OR $(95 \% \mathrm{CI})$ & $3.8(1.8-8.1)$ & $1.3(0.2-7.3)$ & $5(1.6-15.4)$ \\
\hline
\end{tabular}

cated that the log odds for the probability of mortality decreased by 4.43 for every gram increase in mass, with associated OR $=0.01$ (0.01-0.02; Table 3). In other words, an estimated $0.46 \mathrm{~g}$ mean individual mass appeared to protect the spat groups from mortalities by $>10 \%$ when challenged in our experimental conditions.

For OsHV-1 prevalence assessed during thermal challenge, the log odds for the probability of detecting infected individuals also decreased by 4.20 for every gram increase in mass, and the OR was estimated to be $0.01(0-0.12$; Table 3$)$.

\section{Modelling risk factors and thermal challenge effects on OsHV-1 infection and spread}

When considering the entire dataset, highly significant effects were found both

The effect of mean individual mass on OsHV-1 detection at the time of delivery of the groups appeared only marginally significant ( $p>0.05$; Table 3 ), although the estimated coefficient from logistic regression roughly indicated that the probability of detecting the virus tended to decrease with increased weight.

Mean individual mass appeared to have a significant protective effect on infection during the thermal challenge. Estimated parameters of the model indi-

Table 3. Effects of mean individual mass (g) of Pacific oysters Crassostrea gigas on (1) the probability of detecting ostreid herpesvirus 1 (OsHV-1) upon delivery of spat, (2) the probability for 1 spat to die during the thermal challenge and (3) the probability of detecting OsHV-1 during thermal challenge. Wald $(Z)$ values and associated probabilities with exact odds ratios (OR) and $95 \%$ confidence intervals (CI) are shown

\begin{tabular}{|c|c|c|c|c|}
\hline & Mean & $\mathrm{SD}$ & $Z$ & $\mathrm{p}$ \\
\hline \multicolumn{5}{|c|}{ OsHV-1 detection on spat delivery } \\
\hline Intercept & -2.05 & 0.22 & -9.4 & $<0.0001$ \\
\hline Mean mass (slope) & -1.05 & 0.61 & -1.7 & 0.0884 \\
\hline OR $(95 \% \mathrm{CI})$ & $0.3(0.1-1.2)$ & & & \\
\hline \multicolumn{5}{|c|}{ Mortality during thermal challenge } \\
\hline Intercept & 0.2 & 0.06 & 3.4 & 0.0007 \\
\hline Mean mass (slope) & -4.43 & 0.2 & -21.6 & $<0.0001$ \\
\hline OR $(95 \% \mathrm{CI})$ & $0.01(0.01-0.02)$ & & & \\
\hline \multicolumn{5}{|c|}{ OsHV-1 detection during thermal challenge } \\
\hline Intercept & -0.8 & 0.34 & 2.4 & 0.0199 \\
\hline Mean mass (slope) & -4.2 & 1.05 & -3.99 & $<0.0001$ \\
\hline OR $(95 \% \mathrm{CI})$ & $0.01(0-0.12)$ & & & \\
\hline
\end{tabular}

for origin $\left(\chi^{2}=31.82 ; \mathrm{p}<0.0001\right)$ and thermal challenge $\left(\chi^{2}=111.72 ; \mathrm{p}<0.0001\right)$ on ordinal frequency by OsHV-1 class outcome (Fig. 3). When entering the trial, groups of oysters from hatchery production exhibited higher frequencies of individuals in which amounts of viral DNA did not exceed $0.1 \mathrm{VGU}^{-1}$ (94\% for hatchery groups versus $87 \%$ for natural spat groups; Fig. 3a,b). Thermal challenge resulted in a general increase in the frequency by OsHV-1 classes greater than $0.1 \mathrm{VGU} \mathrm{ng}^{-1}$, although heavily infected individuals ( $>1 \mathrm{VGU} \mathrm{ng}^{-1}$ DNA) were found more frequently in oyster spat from natural spat collections than in those from hatchery production (44\% versus $23 \%$; Fig. 3c,d).

Within groups coming from hatchery production, highly significant effects were also found for exposure in the intertidal area $\left(\chi^{2}=21.22 ; \mathrm{p}=\right.$ $0.0002)$ and challenge $\left(\chi^{2}=37.67 ; \mathrm{p}<\right.$ 0.0001 ) on ordinal frequency by OsHV-1 class outcome (Fig. 4). Before entering the thermal challenge, the detection of infected individuals was extremely low (around 1\%) in groups kept away from the intertidal area, whereas $9 \%$ of hatchery spat nurserycultured in the intertidal area exhibited more than 0.1 VGU $\mathrm{ng}^{-1}$ DNA (Fig. 4a,b). The experimental trial re- 


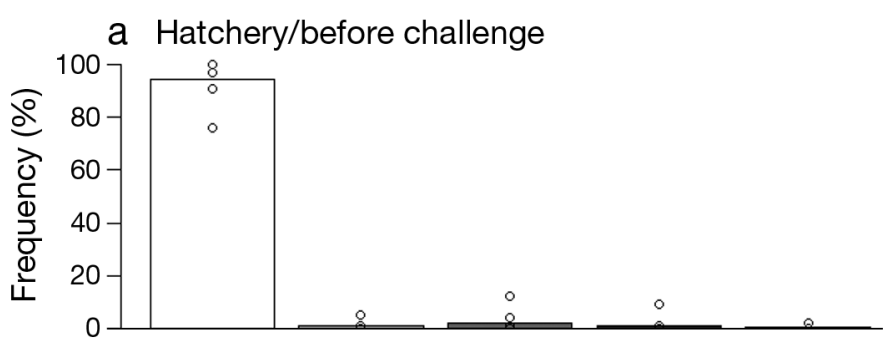

b Natural spat/before challenge

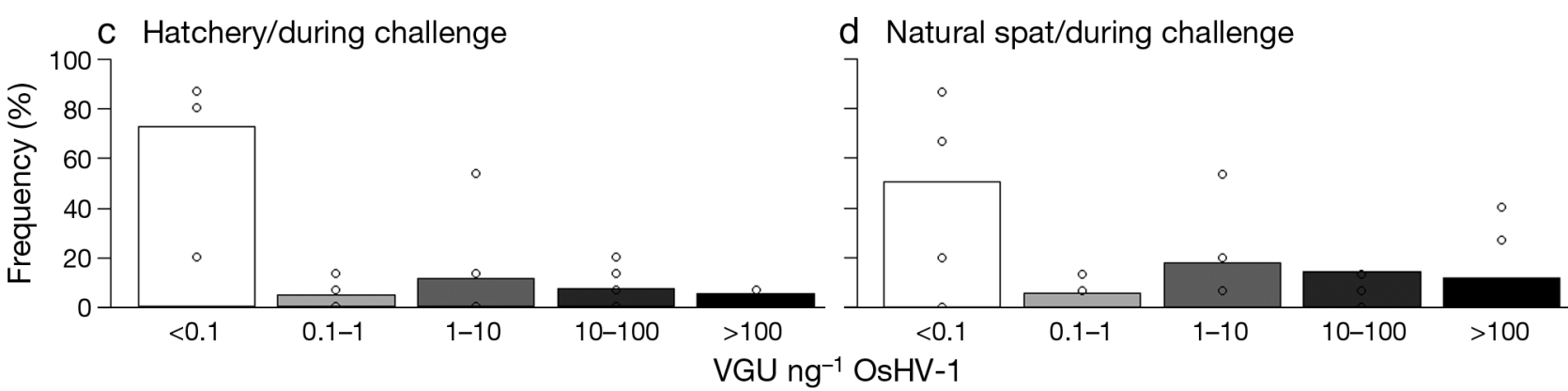

Fig. 3. Frequency (\%) by ostreid herpesvirus 1 (OsHV-1) class for origin of and thermal challenge effects on Pacific oysters Crassostrea gigas. (a) Hatchery spat before challenge (4 groups of 96 ind.), (b) natural spat before challenge (6 groups of 96 ind.), (c) hatchery spat during challenge (4 groups of 15 ind.), (d) natural spat during challenge (6 groups of 15 ind.). Bars represent estimated frequencies from the model; circles represent observed frequencies. VGU: viral genomic units
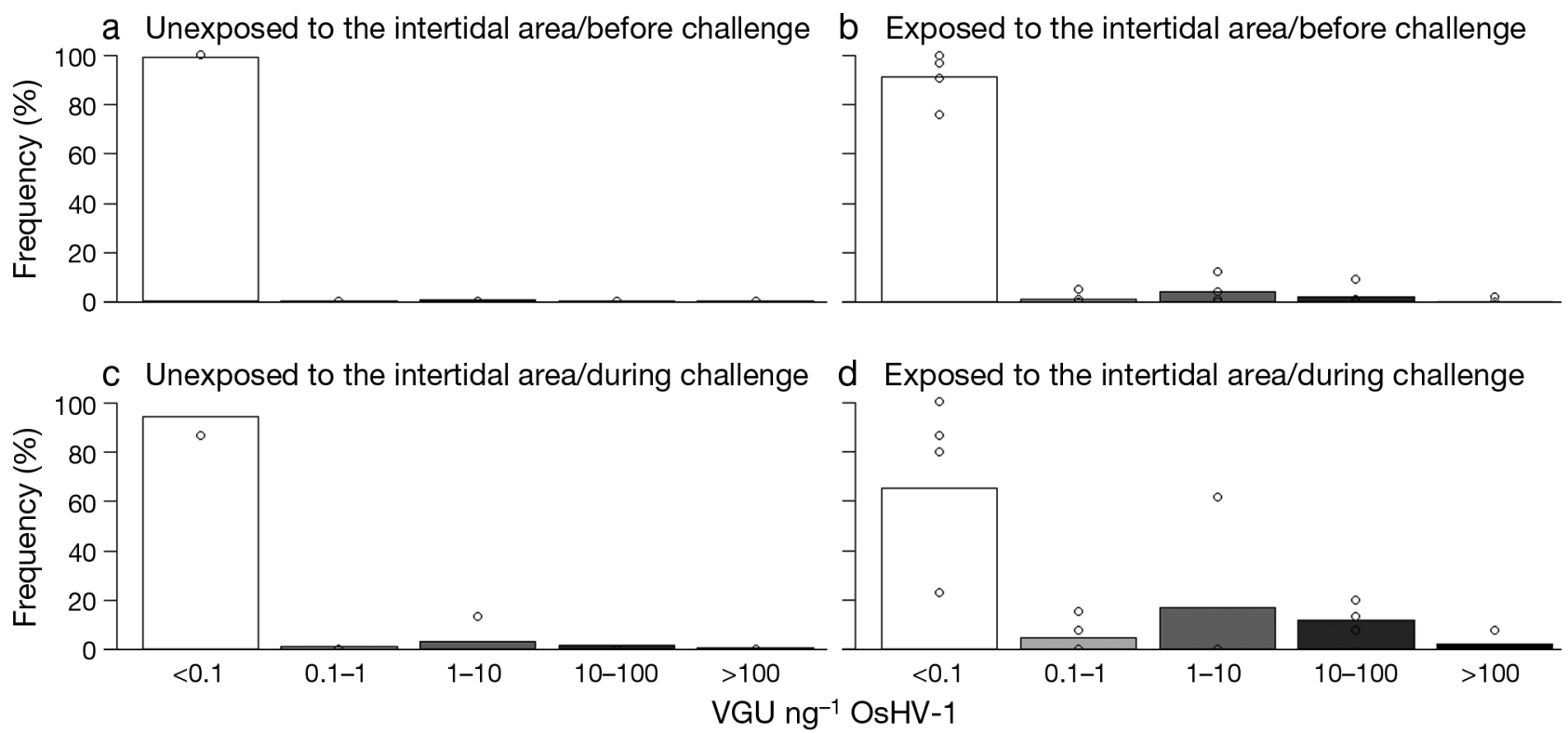

Fig. 4. Frequency (\%) by ostreid herpesvirus 1 (OsHV-1) class for exposure to the intertidal area and thermal challenge effects, within hatchery groups of Pacific oysters Crassostrea gigas. (a) Unexposed to the intertidal area before challenge (2 groups of 96 ind.), (b) exposed to the intertidal area before challenge (4 groups of 96 ind.), (c) unexposed during challenge (2 groups of 15 ind.), (d) exposed during challenge (4 groups of 15 ind.). Bars represent estimated frequencies from the model; circles represent observed frequencies. VGU: viral genomic units

sulted in a general increase in the prevalence of infected individuals in both groups, although infected oysters showing more than $1 \mathrm{VGU}^{\mathrm{ng}}{ }^{-1}$ DNA remained far scarcer in groups maintained in onshore facilities (5 versus $31 \%$, respectively; Fig. $4 \mathrm{c}, \mathrm{d}$ ).
Exposure to the intertidal area during the summer period (when oysters in nearby farms were dying of OsHV-1 infections) and the thermal challenge were also found to have a highly significant effect on frequency by OsHV-1 class (respectively: $\chi^{2}=87.03, \mathrm{p}<$ 
0.0001 and $\chi^{2}=25.48, \mathrm{p}<0.0001 ;$ Fig. 5). When entering the trial, only $5 \%$ of oysters maintained in onshore facilities during the summer exhibited an amount of viral DNA greater than 0.1 VGU $\mathrm{ng}^{-1}$, whereas this proportion reached $14 \%$ for spat reared in the intertidal area during this period (Fig. 5a,b). Thermal challenge resulted in a general increase in the frequency by OsHV-1 class greater than 0.1 VGU $\mathrm{ng}^{-1}$ DNA, although individuals exhibiting more than $1 \mathrm{VGU} \mathrm{ng}^{-1}$ were found more frequently in groups reared in the intertidal area during summer (37 vs. $15 \%$; Fig. 5c,d).

\section{DISCUSSION}

\section{Diagnostic methods}

The 3 methods we used for the early detection of infection offered comprehensive characterization of infection status in spat groups. OsHV-1 detection through qPCR analysis upon delivery was frequent, detecting OsHV-1 DNA in 7 of 10 groups of spat considered in this study. In these groups, initial prevalence varied from 1 to $24 \%$. This finding corroborates results from previous studies that also reported a high degree of OsHV-1 contamination in several groups of spat in France (B. Petton pers. comm.). Thermal challenge also induced mortalities greater than $20 \%$ in 6 of 10 groups. These mortalities led to losses that appeared clearly less than the mortality rates observed in cultivation areas, which usually range from 50 to $100 \%$. This result is consistent with the observations made by Petton et al. (2013) and is probably due to the fact that the experimental trial did not fully re-create field conditions. As the dynamics of infectious diseases are typically related to the density of host populations (e.g. Krkošek 2010), we can hypothesize that relatively low densities as well as isolation from external virus sources limited the contagion and finally tempered the outbreak intensity in the thermal challenge.

No OsHV-1-infected spat were found upon delivery in Groups 3, 5 and 9. Conversely, Groups 8 and 10, which initially exhibited only low prevalence of virus-infected individuals, experienced high mortality in the trial. These results suggest that the proportion of individuals having detectable viral infection on delivery was not the only factor involved in the expression of the disease during the thermal challenge. Given that OsHV-1 $\mu$ Var has become established as the dominant genotype since 2009 (Segarra et al. 2010, Renault et al. 2012), it appears unlikely that the differences we observed in disease expres-
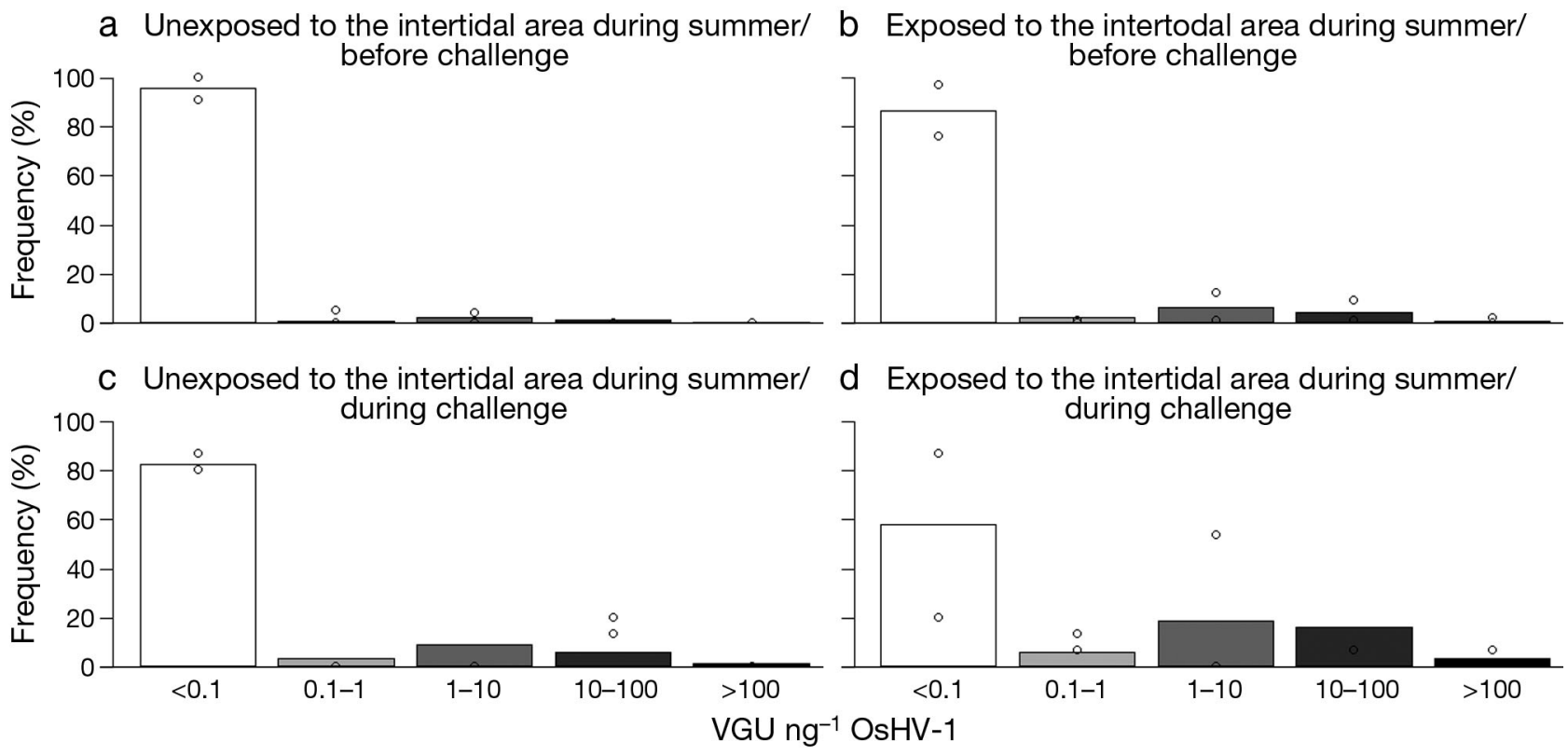

Fig. 5. Frequency (\%) by ostreid herpesvirus 1 (OsHV-1) class for exposure to the intertidal area during summer and thermal challenge effects, within hatchery groups of Pacific oysters Crassostrea gigas exposed to the intertidal area. (a) Unexposed to the intertidal area during summer before challenge (2 groups of 96 ind.), (b) exposed to the intertidal area during summer before challenge (2 groups of 96 ind.), (c) unexposed during challenge (2 groups of 15 ind.), (d) exposed during challenge ( 2 groups of 15 ind.). Bars represent estimated frequencies from the model; circles represent observed frequencies. VGU: viral genomic units 
sion among groups were linked to differences in virulence for several virus strains. One can hypothesize that inter-group variation of resistance may be one of the other determinants of survival probability during the trial.

The thermal challenge trial did induce a clear increase in OsHV-1 detection frequencies in all tested groups. Some oysters were found to be positive for OsHV-1 even in Groups 3, 5 and 9, which appeared initially free from infected individuals and did not exhibit significant mortalities during the trial. In these batches, virus prevalence during the thermal challenge was very low, and the upper values for virus load only reached $10^{3} \mathrm{VGU} \mathrm{ng}^{-1}$. Similar results have been found in another study, more specifically dedicated to test early diagnostic tools (B. Petton pers. comm.). The coupling of the thermal challenge with qPCR in the same diagnostic procedure, even though time-consuming and costly, appeared as the more effective methodology for the early detection of initially latent infections in spat groups.

\section{Risk factors and control strategies}

Biosecurity in aquaculture should be based on early detection of contaminated stocks and infectious sources, in conjunction with management practices preventing later exposure to pathogens (Lightner 2005). In France, cultivation practices are essentially based on rearing in open-water areas, and largescale movements of oysters between cultivation areas are very common. In this context, biosecurity principles would initially appear to be very difficult to apply to the French oyster industry (Mohan et al. 2008, Peeler et al. 2012). Exclusion of OsHV-1infected stocks was nevertheless proposed as a control strategy for spat mortalities, aiming at 2 different objectives. First, onshore rearing in hatcheries allows tight control of inputs. Entry of pathogens may therefore be prevented in such production systems by the strict application of biosecurity-based management practices. Second, limitation of the entry of heavily infected spat stocks in open-water rearing areas has also been envisaged as a potential control strategy, considering that massive or chronic exposure to OsHV-1 could constitute an aggravating factor for oyster seed mortalities.

In our study, OsHV-1 contamination of spat batches was frequent, as viral DNA was detected in all 10 groups of oyster spat during the thermal challenge. This particular result was partially expected, given that previous investigations also reported high prevalence of ostreid herpesvirus in asymptomatic older individuals (Arzul et al. 2002). It also suggests that strict exclusion of OsHV-1-infected stocks from production systems may require a substantial change in spat production practices, considering that viral contamination of spat groups appears to be currently widespread.

Conversely, risk factor analysis suggested that early rearing practices that limit exposure to the field also reduce the probability that OsHV-1 infection will subsequently develop if spat are kept away from external contamination. This finding was supported by only a limited number of observations (i.e. 10 groups) but is corroborated by the results of a largerscale study currently in progress (B. Petton pers. comm.) that includes a larger number of spat groups. A negative correlation was also observed between weight and mortality, and between individual mass and viral detection. We thus hypothesize that bigger oysters are more resistant to viral infection; this finding was partly expected, given that the establishment of genetically determined resistance to OsHV-1 depends on size or age (Dégremont 2013).

In general, our results lead to the obvious conclusion that the use of large-sized spat from hatchery productions, nursery-cultured in onshore facilities, would likely diminish the probability of disease outbreaks in closed production systems. The same recommendation could be made in order to limit the entry of OsHV-1-infected individuals into open-rearing areas, although the effect of such a practice on mortality rates remains uncertain. In fact, the high transmissibility of OsHV-1 (Schikorski et al. 2011a), coupled with the massive outbreaks currently observed in oyster-farming areas (Pernet et al. 2012), should lead to rapid contamination of every spat batch deployed in the field, regardless of the initial prevalence of OsHV-1 in the group. As for any other disease control strategy, such recommendations should be tested in field trials before they are promoted as 'better management practices', offering the possibility of confirming their efficacy, as well as estimated costs and benefits (Turnbull et al. 2011).

\section{Effects of thermal challenge and risk factors for OsHV-1 infection and spread}

The thermal challenge triggered virus replication, characterized in all groups by a clear decrease in the occurrence of individuals presenting $<0.1 \mathrm{VGU} \mathrm{ng}^{-1}$ (and by a resulting increase of the frequencies for all other OsHV-1 classes). During the trial, the OsHV-1 
DNA amounts per individual varied over several orders of magnitude, even among individuals from the same group (as an example, oysters from Group 8 exhibited virus DNA amounts ranging from 0 to $10^{5}$ VGU $\mathrm{ng}^{-1}$ ). Such a result has, to our knowledge, never been published before and supports our analytic approach, which considers frequency by OsHV1 class rather than mean sample values. As a consequence of this high inter-individual variability, the upper values reached here probably correspond to the mean values for OsHV-1 DNA quantification at the height of an outbreak, reported in previous studies (Schikorski et al. 2011a,b), that ranged from $10^{4}$ to $10^{6} \mathrm{VGU} \mathrm{ng}^{-1}$.

The latency-reactivation cycle has been extensively studied for herpesviruses infecting vertebrates (Jones 2003), whereas few studies to date have reported experimental evidence for the reactivation of quiescent OsHV-1 infections in oysters. Our results showed that the trial increased the frequency by OsHV-1 classes $>0.1 \mathrm{VGU} \mathrm{ng}^{-1}$, suggesting that the increase in temperature and/or food availability triggered the reactivation of latent viral infections (Burge et al. 2006). The evidence of virus reactivation supports the hypothesis found in previous publications (Le Deuff et al. 1996, Arzul et al. 2002) which proposed that infected asymptomatic oysters probably play the role of carriers and reservoirs of the virus, promoting OsHV-1 transmission to naïve individuals. This result argues for reconsidering the recommendation of Oden et al. (2011), who proposed as a control strategy the exclusion of infected groups based on mean individual amounts of viral DNA. In fact, our data showed that the amount of OsHV-1 DNA measured at one point in time is clearly transient and that an oyster group could initially appear free of virus (below the limit of detection of 1 diagnostic tool) before revealing the disease when external stimuli induce viral proliferation.

From a theoretical standpoint, the infection process at the individual scale depends mainly on pathogenicity, which controls viral development, and healing processes related to the immunological response and resistance of the host (Hethcote 1989). At the group scale, however, the clear increase in the prevalence of heavily infected individuals observed during the trial probably resulted from internal proliferation occurring at the individual level and crosscontamination among oysters (Hethcote 1989). Moreover, mortalities occurring during the trial could eventually lead to the preferential elimination of heavily infected oysters, finally resulting in the under-representation of such classes of OsHV-1 infection. Due to the high number of processes affecting the resulting frequency by OshV-1 class distribution, our testing design clearly did not allow differentiating one effect from another. This goal will be pursued in subsequent studies, aimed at estimating epidemiological parameters and testing scenarios for disease spread using modelling.

Acknowledgements. We thank the oyster producers for providing the spat used in this study. We gratefully acknowledge the skilful assistance of the Synergie Mer Littoral, Université de Caen Basse Normandie and Ifremer technical staff involved in oyster testing and molecular analyses. We also thank Philippe Riou and Coralie Picoche, who provided useful discussion and comments on earlier drafts of the manuscript, and we are especially grateful to Susan Ford for help with editing the English.

\section{LITERATURE CITED}

Ananth CV, Kleinbaum DG (1997) Regression models for ordinal responses: a review of methods and applications. Int J Epidemiol 26:1323-1333

Arzul I, Renault T, Thébault A, Gérard A (2002) Detection of oyster herpesvirus DNA and proteins in asymptomatic Crassostrea gigas adults. Virus Res 84:151-160

Burge CA, Friedman CS (2012) Quantifying ostreid herpesvirus (OsHV-1) genome copies and expression during transmission. Microb Ecol 63:596-604

Burge CA, Griffin FJ, Friedman CS (2006) Mortality and herpesvirus infections of the Pacific oyster Crassostrea gigas in Tomales Bay, California, USA. Dis Aquat Org 72: $31-43$

Chávez-Villalba J, Villelas-Avila R, Cáceres-Martínez C (2007) Reproduction, condition and mortality of the Pacific oyster Crassostrea gigas (Thunberg) in Sonora, México. Aquacult Res 38:268-278

Cheney DP, MacDonald BF, Elston RA (2000) Summer mortality of Pacific oysters, Crassostrea gigas (Thunberg): initial findings on multiple environmental stressors in Puget Sound, Washington, 1998. J Shellfish Res 19: 353-359

Chongsuvivatwong V (2012) Epicalc: epidemiological calculator. R package version 2.15.1.0. Available at http:// cran.r-project.org/web/packages/epicalc/ (accessed 23 Oct 2013)

> Davison AJ, Eberle R, Ehlers B, Hayward GS and others (2009) The order Herpesvirales. Arch Virol 154: 171-177

Dégremont L (2011) Evidence for herpesvirus (OsHV-1) resistance in juvenile Crassostrea gigas selected for high resistance to summer mortality phenomenon. Aquaculture 317:94-98

> Dégremont L (2013) Size and genotype affect resistance to mortality caused by OsHV-1 in Crassostrea gigas. Aquaculture 416-417:129-134

> Farley CA, Banfield VG, Kasnic GJ, Foster WS (1972) Oyster herpes-type virus. Science 178:759-760

Hethcote HW (1989) Three basic epidemiological models. In: Levins SA, Hallam TG, Gross L (eds) Applied mathematical ecology. Springer-Verlag, Berlin, p 119-144 
Jenkins C, Hick P, Gabor M, Spiers Z and others (2013) Identification and characterisation of an ostreid herpesvirus-1 microvariant (OsHV-1 $\mu$-var) in Crassostrea gigas (Pacific oysters) in Australia. Dis Aquat Org 105:109-126

$>$ Jones C (2003) Herpes simplex virus type 1 and bovine herpesvirus 1 latency. Clin Microbiol Rev 16:79-95

Jouaux A, Lafont M, Blin JL, Houssin M, Mathieu M, Lelong C (2013) Physiological change under OsHV-1 contamination in Pacific oyster Crassostrea gigas through massive mortality events on fields. BMC Genomics 14:590, doi:10.1186/1471-2164-14-590

Krkošek M (2010) Host density thresholds and disease control for fisheries and aquaculture. Aquacult Environ Interact 1:21-32

$>$ Le Deuff RM, Renault T, Gérard A (1996) Effects of temperature on herpes-like virus detection among hatcheryreared larval Pacific oyster Crassostrea gigas. Dis Aquat Org 24:149-157

Lightner DV (2005) Biosecurity in shrimp farming: pathogen exclusion through use of SPF stock and routine surveillance. J World Aquacult Soc 36:229-248

Martenot C, Oden E, Travaille E, Malas JP, Houssin M (2010) Comparison of two real-time PCR methods for detection of ostreid herpesvirus 1 in the pacific oyster Crassostrea gigas. J Virol Methods 170:86-89

Mohan CV, Philips MJ, Bhat BV, Umesh NR, Padiyar PA (2008) Farm-level plans and husbandry measures for aquatic animal disease emergencies. Rev Sci Tech Off Int Epizoot 27:161-173

Mori K (1979) Effects of artificial eutrophication on the metabolism of the Japanese oyster Crassostrea gigas. Mar Biol 53:361-369

> Murray AG, Marcos-Lopez M, Collet B, Munro LA (2012) A review of the risk posed to Scottish mollusc aquaculture from Bonamia, Marteilia and oyster herpes virus. Aquaculture 370-371:7-13

Nicolas JL, Comps M, Cochennec N (1992) Herpes-like virus infecting Pacific oyster larvae, Crassostrea gigas. Bull Eur Assoc Fish Pathol 12:11-13

> Oden E, Martenot C, Travaille E, Malas JP, Houssin M (2011) Quantification of ostreid herpesvirus (OsHV-1) in Crassostrea gigas by real time PCR: determination of a viral load threshold to prevent summer mortalities. Aquaculture 317:27-31

Peeler EJ, Reese AR, Cheslett DL, Geoghegan F, Power A, Thrush MA (2012) Investigation of mortality in Pacific oysters associated with Ostreid herpesvirus-1 $\mu$ Var in the Republic of Ireland in 2009. Prev Vet Med 105:136-143

Pepin JF, Riou A, Renault T (2008) Rapid and sensitive detection of ostreid herpesvirus 1 in oyster samples by real-time PCR. J Virol Methods 149:269-276

Pernet F, Barret J, Marty C, Moal J, Le Gall P, Boudry P (2010) Environmental anomalies, energetic reserves and fatty acid modifications in oysters coincide with an exceptional mortality event. Mar Ecol Prog Ser 401: 129-146

Pernet F, Barret J, Le Gall P, Corporeau C and others (2012) Mass mortalities of Pacific oysters Crassostrea gigas reflect infectious diseases and vary with farming prac-

Editorial responsibility: Mike Hines,

Fouras, France tices in the Mediterranean Thau lagoon, France. Aquacult Environ Interact 2:215-237

Petton B, Pernet F, Robert R, Boudry P (2013) Temperature influence on pathogen transmission and subsequent mortalities in juvenile Pacific oysters Crassostrea gigas. Aquacult Environ Interact 3:257-273

Pouvreau S, Bourles Y, Lefebvre S, Gangnery A, AlunnoBruscia M (2006) Application of a dynamic energy budget model to the Pacific oyster, Crassostrea gigas, reared under various environmental conditions. J Sea Res 56:156-167

Renault T, Cochennec N, Le Deuff RM, Chollet B (1994) Herpes-like virus infecting Japanese oyster (Crassostrea gigas) spat. Bull Eur Assoc Fish Pathol 14:64-66

$>$ Renault T, Le Deuff RM, Chollet B, Cochennec N, Gérard A (2000a) Concomitant herpes-like virus infections in hatchery-reared larvae and nursery-cultured spat Crassostrea gigas and Ostrea edulis. Dis Aquat Org 42:173-183

Renault T, Le Deuff RM, Lipart C, Delsert C (2000b) Development of a PCR procedure for the detection of a herpeslike virus infecting oysters in France. J Virol Methods 88: $41-50$

> Renault T, Moreau P, Faury N, Pepin JF, Ségarra A, Webb S (2012) Analysis of clinical ostreid herpesvirus 1 (Malacoherpesviridae) specimens by sequencing amplified fragments from three virus genome areas. J Virol 86: 5942-5947

Ripley B, Venables B, Hornik K, Gebhardt A, Firth D (2013) MASS: function and data sets to support Venables and Ripley 'Modern Applied Statistics with S'. R package version 7.3-26. Available at http://cran.r-project.org/web/ packages/MASS/ (accessed 23 October 2013)

Samain JF, Dégremont L, Soletchnik P, Haure J and others (2007) Genetically based resistance to summer mortality in the Pacific oyster (Crassostrea gigas) and its relationship with physiological, immunological characteristics and infection process. Aquaculture 268:227-243

> Saulnier D, De Decker S, Haffner P, Cobret L, Robert M, Garcia C (2010) A large-scale epidemiological study to identify bacteria pathogenic to Pacific oyster Crassostrea gigas and correlation between virulence and metalloprotease-like activity. Microb Ecol 59:787-798

> Schikorski D, Faury N, Pepin JF, Saulnier D, Tourbiez D, Renault T (2011a) Experimental ostreid herpesvirus 1 infection of the Pacific oyster Crassostrea gigas: kinetics of virus DNA detection by q-PCR in seawater and in oyster samples. Virus Res 155:28-34

- Schikorski D, Renault T, Saulnier D, Faury N, Moreau P, Pépin JF (2011b) Experimental infection of Pacific oyster Crassostrea gigas spat by ostreid herpesvirus 1: demonstration of oyster spat susceptibility. Vet Res 42:1-13

Segarra A, Pépin JF, Arzul I, Morga B, Faury N, Renault T (2010) Detection and description of a particular Ostreid herpesvirus 1 genotype associated with massive mortality outbreaks of Pacific oysters, Crassostrea gigas, in France in 2008. Virus Res 153:92-99

Turnbull JF, Berril IK, Green DM, Kaye R and others (2011) Applied epidemiology with examples from UK aquaculture. Aquacult Res 42(Suppl s1):21-27

Submitted: October 30, 2012; Accepted: April 28, 2014

Proofs received from author(s): July 11, 2014 